\title{
Morphological and Physiological Analysis of Bio-Control Agent (Trichoderma viride)
}

\author{
R.P. Mishra ${ }^{1 *}$, Manjul Pandey ${ }^{2}$ and Mukesh Srivastava ${ }^{1}$ \\ ${ }^{1}$ Department of Plant Pathology, C.S.A. University of Agriculture and Technology, \\ Kanpur-208002, India \\ ${ }^{2}$ Department of Plant Pathology, Krishi Vigyan Kendra, Banda, India \\ *Corresponding author
}

\begin{abstract}
A B S T R A C T
Trichoderma are free-living fungi and found commonly in soil - root ecosystem. They are highly interactive in root, soil and foliar environments. They produce or release a variety of compound that induces localized or systemic resistance responses in plant. In this investigation ten different synthetic media (TSM, PDA, Asthana \& Hawkers, Richard's agar, Sabouraud's dextrose, Rose Bengal agar, Czapex Dox, Beef extract agar, Cooke rose Bengal and Pikovaskys agar) used to study the morphological and cultural characters of the bio-control agent. Potato dextrose agar (PDA) medium supported the best growth of the bio-agent followed by Trichoderma specific medium (TSM), Pikovakyas agar and Rose Bengal medium. Beef extract agar medium supported the lowest growth of this fungus. Excellent sporulation obtained on Potato Dextrose Agar and Trichoderma Specific Medium. It was good on Pikovakyas Agar, Rose Bengal Agar and Sabouraud Agar, fair on Asthana \& Hawker, Cooke Rose Bengal Agar, Czapak-dox Agar and Richard Agar, while poor on Beef Extract Agar medium. The maximum colony growth of the mycelium was observed at $25^{\circ} \mathrm{C}$. The statistical analysis showed that isolate T1 $(8 \mathrm{CP})$ exhibited the highest growth which was significantly superior to other isolates. Rests of the isolates were at par with each other. The maximum dry weight recorded as $208.81 \mathrm{mg}, 205.80 \mathrm{mg}$, $209.17 \mathrm{mg}, 207.11 \mathrm{mg}, 206.00 \mathrm{mg}$, and $208.14 \mathrm{mg}$ at $\mathrm{pH} 7.0$. The minimum dry weight recorded at $\mathrm{pH}$ 4.0. Thus, excellent sporulation was recorded at $\mathrm{pH} 6.5$ and 7.0. It has observed that neither alkaline nor acidic conditions are congenial for the growth and sporulation of the bio-agent.
\end{abstract}

\section{Keywords}

Morphology, Sporulation, Synthetic media, $\mathrm{pH}$, Temperature and $T$. viride

Article Info

Accepted:

12 April 2018 Available Online: 10 May 2018

\section{Introduction}

Trichoderma strains have been recognized as biological agent for the control of plant diseases. It has ability to increase root growth and development, crop productivity, resistance to abiotic stresses and uptake and use of nutrients are its important characteristics.
Trichoderma sp. are free-living fungi that are common in soil and root ecosystems (Kubicek and Penttilame 1998). They are highly interactive in root, soil and foliar environments. They produce or release a variety of compound that induces localized or systemic resistance responses in plant (Harman et al., 1996). Trichoderma 
commonly available in soil and root ecosystem has gained immense importance since, last few decades due to its biological control ability against several plant pathogens Devi et al., (2012) studied the morphological characters with antagonistic ability of Trichoderma species. Based on morphological and cultural characteristics, the Trichoderma isolates identified as $T$. virens (11 isolates), $T$. asperellum (15 isolates), T. harzianum (14 isolates) and T. longibrachiatum (32 isolates). Mustafa et al., (2009) were examined on five different culture media including Potato Dextrose Agar, Waksman Agar, Agar-Agar, Czapeck's Dox Agar and Corn Meal Agar. The medium had a significant effect on growth rate and population of the three Trichoderma species. Potato Dextrose Agar was the best medium in terms of growth, spore production and biomass. Jayaswal et al., (2003) recorded optimum growth and sporulation of Trichoderma viride between $\mathrm{pH} 4.5$ to 5.5. The growth and sporulation decreased with either decreasing the $\mathrm{pH}$ below 4.5 or above 5.5 respectively, above $\mathrm{pH} 6.0$ with increasing the $\mathrm{pH}$, the growth and sporulation decreased proportionately. At $\mathrm{pH} 8.0$ and 8.5 the growth and sporulation were very poor. At $\mathrm{pH} 9$, no growth of $T$. viride was observed. Trichoderma viride showed a high range of temperature tolerance, it grew and sporulated well between temperatures 20 to $35^{\circ} \mathrm{C}$.

\section{Materials and Methods}

\section{Effect of different media on growth of bio- control agent}

Following ten different synthetic media (Trichoderma specific medium (Elad et al., 1981), Potato Dextrose Agar (Lawrence C. Parks, 1997), Asthana \& Hawkers (Dandge V. S, 2012), Richard's agar (Williams et al., 2000), Sabouraud's Dextrose agar (Guinea et al., 2005), Rose Bengal agar (Smith et al.,1944), Czapeks Dox (Thom and Church,
1926), Beef extract agar (Vanderzant et al., 1992), Cooke rose Bengal agar (Cooke, 1954) and Pikovaskys agar medium (Sundara Rao . and Sinha, 1963) used to study the morphological and cultural characters of the bio-control agent. The studies carried out to determine the linear growth rate of the identified bio-agent Trichoderma viride. $20 \mathrm{ml}$ each sterilized media poured in to $90 \mathrm{~mm}$ size Petri dishes. The plates inoculated with $5 \mathrm{~mm}$ disc of inoculums cut with the help of sterilized cork borer from seven-day-old culture in three replications. The plates incubated at $23+2^{0} \mathrm{C}$ for 7 days. After incubation of seven days linear growth of the bio-agent recorded in two directions regularly and then, average linear growth of three replicated Petri plates of each bio-agents were taken for statistical analysis.

\section{Effect of temperature on growth of bio agent}

To find out optimum and suitable temperatures for the growth of bio control agent (Trichoderma sp.), the micro-organism grown at five different temperatures on Potato dextrose agar medium. Inoculation of pure culture of Trichoderma viride with help sterile cook borer in Petri plate. The inoculated Petri plates kept at $15,20,25,30$ and $35^{\circ} \mathrm{C}$ in BOD incubator and the daily observation recorded. For each temperature petri plates were inoculated with seven days old culture of bioagent ( $T$. viride) with help of sterile cook borer and kept at 15,20,25, 30 and $35^{\circ} \mathrm{C}$ in BOD incubator and data recorded after daily observation.

\section{Effect of pH on growth of the bio-agent}

To find out optimum as well as suitable $\mathrm{pH}$ for the growth of Trichoderma viride. The set of different $\mathrm{pH}$ values $(4.0,4.5,5.0,5.5,6.0,6.5$, 7.0, 7.5, and 8.0) was adjusted by adding appropriate amount of citrate phosphate buffer 
before sterilization. For each $\mathrm{pH}$ value three replications used. The spore count was recorded by using hemocytometer as $1 \times 10^{5}$ spore $/ \mathrm{ml}$. $1 \mathrm{ml}$ of this spore suspension was added in Potato Dextrose broth of different $\mathrm{pH}$ ranges and then kept in BOD incubator at $23+$ $2^{0} \mathrm{C}$ for 7 days. After 7 days, mycelium mat harvested by sterilized filter paper. The harvested mycelium was kept in hot air oven at $60^{\circ} \mathrm{C}$ for $48 \mathrm{~h}$ for dry weight and final dry weight of mycelium was measure in $\mathrm{mg}$.

\section{Results and Discussion}

\section{Morphological studies of bio control agent}

Isolated fungus showed typical fast growth at $25-30^{\circ} \mathrm{C}$ but will not grow at $35^{\circ} \mathrm{C}$. Colonies are transparent at first on Potato dextrose agar medium. A yellow pigment secreted in medium. Under the study of such microorganism showed highly branched conidiophores and main branches of the conidiophores produce lateral branches that paired or not, the longest branches distant from the tip.

The secondary branches often paired and longest secondary branches being closet to the main axis. All primary and secondary branches arise at or near $90^{\circ}$ with respect to the main axis. Sheila and Odhiambo (2009) isolated green fungus from 120 soil samples.

Colony characteristics, growth rate in culture and morphological characters are used for identification. Nashwa et al., (2008) collected soil samples for isolation of Trichoderma spp. from the rhizosphere of healthy been plants using dilution plate techniques and purified by the single spore method. They observed that conidia of Trichoderma are ellipsoidal and typically smooth. Synamorphos are formed and recognized by their solitary conidiophores that are vertically branched and bear conidia at the tip of each phialide. Chlamydospores produced by all species of Trichoderma but not all species produces Chlamydospores on PDA at $20^{\circ} \mathrm{C}$ within 10 days. Chlamydospore were typically unicellular sub-globose and short hyphae; they formed with hyphal cells.

\section{Effect of different media on growth of bio- agent}

The bioagent (Trichoderma viride) grown on the solid states of ten media for 10 days at $28 \pm 1^{\circ} \mathrm{C}$ temperature. The average diameter of the colonies, the nature and spoliation on different media recorded and the data presented in table 1 are summarized.

It is evident from the table that Potato dextrose agar medium supported the best growth of the bio-agent followed by Trichoderma specific medium, Pikovakyas agar and Rose Bengal medium. Beef extract agar medium supported the lowest growth of the fungus. It is also obvious from table that excellent spoliation obtained on Potato Dextrose Agar and Trichoderma Specific Medium.

It was good on Pikovakyas Agar, Rose Bengal Agar and Sabouraud's Dextrose Agar, fair on Asthana \& Hawker, Cooke Rose Bengal Agar, Czapak-dox Agar and Richard Agar, while poor on Beef Extract Agar medium. Mustafa et al., (2009) examined on five different culture media including Potato Dextrose Agar, Waksman agar, Agar-agar, Czepak's agar and Corn Meal agar.

The medium had a significant effect on growth rate on population of the three Trichoderma species. Potato Dextrose Agar was the best medium in terms of growth spore production and biomass yield. Farooq et al., (2005) were studied In vitro effect of culture media on mycelial growth of $F$. oxysporum $\mathrm{f}$. sp. ciceri. The fungus grew the best on Czapek dox agar and chickpea seed-meal agar media among eight culture media that were tried. 
Table.1 Effect of different media on growth of bio-agent

\begin{tabular}{|c|c|c|c|c|c|c|c|c|c|c|c|c|}
\hline $\mathbf{S}$ & Media & $\hat{\mho}_{\infty}$ & $\underline{\theta}$ & $\begin{array}{l}\hat{0} \\
-1\end{array}$ & $\begin{array}{l}\hat{\vartheta} \\
\tilde{m}\end{array}$ & $\begin{array}{l}\hat{\vartheta} \\
\text { ले }\end{array}$ & $\begin{array}{l}\hat{\vartheta} \\
\text { है }\end{array}$ & $\begin{array}{l}\hat{v} \\
\hat{\theta}\end{array}$ & $\begin{array}{l}\hat{\theta} \\
\text { \&े }\end{array}$ & $\begin{array}{l}\hat{\theta} \\
\tilde{\theta} \\
\tilde{\theta}\end{array}$ & $\begin{array}{l}\hat{\theta} \\
\hat{\theta}\end{array}$ & Sporulation \\
\hline 1 & Potato dextrose agar & $\begin{array}{c}6 . \\
8\end{array}$ & $\begin{array}{c}6 . \\
1\end{array}$ & $\begin{array}{l}6 . \\
7\end{array}$ & $\begin{array}{l}6 . \\
8\end{array}$ & $\begin{array}{l}6 . \\
6\end{array}$ & $\begin{array}{c}6 . \\
1\end{array}$ & $\begin{array}{l}6 . \\
3\end{array}$ & $\begin{array}{l}6 . \\
6\end{array}$ & 6.0 & 6.1 & Excellent \\
\hline 2 & $\begin{array}{l}\text { Trichoderma } \\
\text { selective media }\end{array}$ & $\begin{array}{c}6 . \\
1\end{array}$ & $\begin{array}{l}5 . \\
9\end{array}$ & $\begin{array}{l}6 . \\
5\end{array}$ & $\begin{array}{l}6 . \\
6\end{array}$ & $\begin{array}{l}6 . \\
1\end{array}$ & $\begin{array}{l}6 . \\
0\end{array}$ & $\begin{array}{l}6 . \\
5\end{array}$ & $\begin{array}{l}6 . \\
2\end{array}$ & 6.1 & 5.9 & Excellent \\
\hline 3 & Rose Bengal agar & $\begin{array}{l}5 . \\
5\end{array}$ & $\begin{array}{l}5 . \\
1\end{array}$ & $\begin{array}{l}5 . \\
1\end{array}$ & $\begin{array}{l}5 . \\
7\end{array}$ & $\begin{array}{l}5 . \\
6\end{array}$ & $\begin{array}{l}5 . \\
5\end{array}$ & $\begin{array}{l}5 . \\
7\end{array}$ & $\begin{array}{l}5 . \\
3\end{array}$ & 5.8 & 5.5 & Good \\
\hline 4 & Pikovakyas agar & $\begin{array}{l}5 . \\
8\end{array}$ & $\begin{array}{l}5 . \\
3\end{array}$ & $\begin{array}{l}5 . \\
6\end{array}$ & $\begin{array}{l}6 . \\
0\end{array}$ & $\begin{array}{l}5 . \\
0\end{array}$ & $\begin{array}{l}4 . \\
8\end{array}$ & $\begin{array}{l}5 . \\
8\end{array}$ & $\begin{array}{l}5 . \\
6\end{array}$ & 5.5 & 5.8 & Good \\
\hline 5 & $\begin{array}{l}\text { Sabouraud dextrose } \\
\text { agar }\end{array}$ & $\begin{array}{l}5 . \\
0\end{array}$ & $\begin{array}{c}5 . \\
1\end{array}$ & $\begin{array}{l}4 . \\
6\end{array}$ & $\begin{array}{l}4 . \\
9\end{array}$ & $\begin{array}{l}4 . \\
0\end{array}$ & $\begin{array}{l}4 . \\
2\end{array}$ & $\begin{array}{l}5 . \\
0\end{array}$ & $\begin{array}{l}5 . \\
2\end{array}$ & 5.5 & 5.2 & Good \\
\hline 6 & Asthana \& Hawker & $\begin{array}{l}4 . \\
5\end{array}$ & $\begin{array}{l}4 . \\
2\end{array}$ & $\begin{array}{l}4 . \\
3\end{array}$ & $\begin{array}{l}4 . \\
3\end{array}$ & $\begin{array}{c}4 . \\
1\end{array}$ & $\begin{array}{l}3 . \\
9\end{array}$ & $\begin{array}{l}4 . \\
9\end{array}$ & $\begin{array}{l}5 . \\
0\end{array}$ & 5.0 & 4.8 & Fair \\
\hline 7 & $\begin{array}{l}\text { Cooke rose Bengal } \\
\text { agar }\end{array}$ & $\begin{array}{l}4 . \\
0\end{array}$ & $\begin{array}{c}4 . \\
1\end{array}$ & $\begin{array}{l}4 . \\
1\end{array}$ & $\begin{array}{l}4 . \\
8\end{array}$ & $\begin{array}{l}4 . \\
7\end{array}$ & $\begin{array}{l}4 . \\
2\end{array}$ & $\begin{array}{l}4 . \\
0\end{array}$ & $\begin{array}{l}4 . \\
2\end{array}$ & 4.1 & 4.4 & Fair \\
\hline 8 & Czapak dox agar & $\begin{array}{l}4 . \\
0\end{array}$ & $\begin{array}{l}3 . \\
9\end{array}$ & $\begin{array}{l}4 . \\
2\end{array}$ & $\begin{array}{l}4 . \\
0\end{array}$ & $\begin{array}{l}3 . \\
9\end{array}$ & $\begin{array}{l}3 . \\
8\end{array}$ & $\begin{array}{l}3 . \\
9\end{array}$ & $\begin{array}{l}4 . \\
3\end{array}$ & 4.0 & 4.1 & Fair \\
\hline 9 & Beef extract agar & $\begin{array}{l}3 . \\
8\end{array}$ & $\begin{array}{l}3 . \\
5\end{array}$ & $\begin{array}{l}4 . \\
0\end{array}$ & $\begin{array}{l}3 . \\
9\end{array}$ & $\begin{array}{l}4 . \\
0\end{array}$ & $\begin{array}{l}3 . \\
9\end{array}$ & $\begin{array}{l}3 . \\
7\end{array}$ & $\begin{array}{l}3 . \\
1\end{array}$ & 3.6 & 3.5 & Poor \\
\hline $\begin{array}{l}1 \\
0\end{array}$ & Richard agar & $\begin{array}{l}4 . \\
1\end{array}$ & $\begin{array}{l}4 . \\
5\end{array}$ & $\begin{array}{l}4 . \\
0\end{array}$ & $\begin{array}{l}4 . \\
1\end{array}$ & $\begin{array}{l}4 . \\
0\end{array}$ & $\begin{array}{c}4 . \\
1\end{array}$ & $\begin{array}{l}4 . \\
0\end{array}$ & $\begin{array}{l}4 . \\
3\end{array}$ & 4.2 & 4.4 & Fair \\
\hline
\end{tabular}

Table.2 Effect of different temperatures on growth of bio-agent

\begin{tabular}{|c|c|c|c|c|c|}
\hline \multirow{2}{*}{$\begin{array}{l}\text { Temperature } \\
\text { T. viride } \\
\text { isolates }\end{array}$} & \multicolumn{5}{|c|}{ Mycelial weight (gm) } \\
\hline & 15 & 20 & 25 & 30 & 35 \\
\hline $08 \mathrm{CP}$ & 20.34 & 40.13 & 64.59 & 59.00 & 34.54 \\
\hline $11 \mathrm{CP}$ & 19.45 & 38.23 & 58.64 & 60.15 & 33.05 \\
\hline $17 \mathrm{CP}$ & 21.15 & 41.07 & 62.09 & 60.10 & 31.00 \\
\hline $33 \mathrm{CP}$ & 20.89 & 39.22 & 61.20 & 59.00 & 30.50 \\
\hline $34 \mathrm{CP}$ & 23.10 & 41.18 & 62.47 & 57.10 & 27.90 \\
\hline $35 \mathrm{CP}$ & 22.12 & 40.33 & 60.00 & 56.74 & 28.20 \\
\hline $66 \mathrm{CP}$ & 23.00 & 40.13 & 62.30 & 59.72 & 29.52 \\
\hline $89 \mathrm{CP}$ & 22.41 & 41.00 & 62.52 & 59.31 & 30.14 \\
\hline $102 \mathrm{CP}$ & 22.35 & 40.27 & 61.08 & 60.64 & 31.28 \\
\hline $119 \mathrm{CP}$ & 23.18 & 40.57 & 62.73 & 61.20 & 31.77 \\
\hline
\end{tabular}

$\mathrm{CD}$ at $5 \%=1.048$ 
Table.3 Effect of $\mathrm{pH}$ on growth of the bio-agent

\begin{tabular}{|l|l|l|l|l|l|l|l|l|l|l|}
\hline pH & $8 \mathrm{CP}$ & $11 \mathrm{CP}$ & $17 \mathrm{CP}$ & $33 \mathrm{CP}$ & $34 \mathrm{CP}$ & $35 \mathrm{CP}$ & $66 \mathrm{CP}$ & $89 \mathrm{CP}$ & $102 \mathrm{CP}$ & $119 \mathrm{CP}$ \\
\hline
\end{tabular}

\begin{tabular}{|l|l|l|l|l|l|l|l|l|l|l|}
\hline 4.0 & 114.73 & 116.66 & 112.50 & 111.57 & 117.90 & 114.75 & 113.97 & 111.29 & 112.08 & 112.37 \\
\hline
\end{tabular}

\begin{tabular}{|l|l|l|l|l|l|l|l|l|l|l|l|}
\hline 4.5 & 128.42 & 135.64 & 126.87 & 125.40 & 125.07 & 124.68 & 125.38 & 125.67 & 124.87 & 126.01 \\
\hline
\end{tabular}

\begin{tabular}{|l|l|l|l|l|l|l|l|l|l|l|}
\hline 5.0 & 159.54 & 161.30 & 154.73 & 151.29 & 149.37 & 145.27 & 158.23 & 159.12 & 160.43 & 149.00 \\
\hline
\end{tabular}

\begin{tabular}{|l|l|l|l|l|l|l|l|l|l|l|l|}
\hline 5.5 & 178.67 & 185.00 & 176.14 & 175.67 & 169.20 & 161.46 & 168.03 & 169.33 & 169.82 & 170.20 \\
\hline
\end{tabular}

\begin{tabular}{|l|l|l|l|l|l|l|l|l|l|l|l|}
\hline 6.0 & 185.31 & 189.25 & 182.29 & 188.63 & 181.19 & 179.00 & 172.91 & 171.38 & 172.11 & 173.61 \\
\hline
\end{tabular}

\begin{tabular}{|l|l|l|l|l|l|l|l|l|l|l|l}
\hline 6.5 & 192.46 & 191.70 & 191.52 & 190.32 & 190.66 & 186.10 & 189.00 & 190.03 & 190.68 & 191.11 \\
\hline
\end{tabular}

\begin{tabular}{|l|l|l|l|l|l|l|l|l|l|l|l|}
\hline 7.0 & 208.81 & 205.80 & 209.17 & 207.11 & 206.00 & 208.14 & 207.91 & 208.89 & 209.13 & 207.14 \\
\hline
\end{tabular}

\begin{tabular}{|l|l|l|l|l|l|l|l|l|l|l|l}
\hline 7.5 & 197.27 & 198.32 & 197.23 & 196.20 & 196.09 & 195.19 & 192.33 & 193.45 & 194.30 & 194.56 \\
\hline
\end{tabular}

\begin{tabular}{|l|l|l|l|l|l|l|l|l|l|l|}
8.0 & 123.44 & 121.41 & 129.00 & 127.30 & 128.00 & 123.00 & 122.62 & 121.50 & 123.51 & 124.90 \\
\hline
\end{tabular}

$\mathrm{CD}$ at $5 \%=13.158$

\section{Physiological studies}

\section{Effect of different temperatures on growth of bio-agent}

In order to find optimum as well as suitable temperature for the growth of bio-agent, they were grown at five different temperatures on Potato dextrose agar medium. After 10 days incubation the mycelia dry weight recorded and presented in table 2 .

It is evident from the table that the growth of the microorganism increased up to $25^{0} \mathrm{Ctemperature,} \mathrm{there} \mathrm{after} \mathrm{the} \mathrm{growth} \mathrm{starts}$ decreasing. The maximum colony growth of the mycelium was observed at $25^{\circ} \mathrm{C}$. The growth of the bio-agent significantly affected with either increase or decrease in temperature. The statistical analysis shows that isolate T1 (8 CP) exhibited the highest growth which was significantly superior to other isolates. Rest of the isolates was at par with each other. Choi et al., (2003) conducted study to investigate physiological characteristics of Trichoderma spp. isolated from Pleurotus sp. The optimal growth temperature of Trichoderma spp. was $27 \sim 30^{\circ} \mathrm{C}$. Although T. longibrachiatum was able to grow at $37^{\circ} \mathrm{C}$. Trichoderma viride showed a high range of temperature tolerance, it grew and sporulated well between temperatures 20 to $35^{\circ} \mathrm{C}$ according to Jayaswal et al., (2003)

\section{Effect of pH on growth of the bio-agent}

The observations standardized $1 \times 10^{5}$ spores $/ \mathrm{ml}$ presented in table 3 .

It is evident from the table that the maximum dry weight recorded as $208.81 \mathrm{mg}, 205.80 \mathrm{mg}$, $209.17 \mathrm{mg}, 207.11 \mathrm{mg}, 206.00 \mathrm{mg}$, and $208.14 \mathrm{mg}$ at $\mathrm{pH}$ 7.0. The minimum dry weight recorded at $\mathrm{pH}$ 4.0. Thus, excellent sporulation was recorded at $\mathrm{pH} 6.5$ and 7.0. It has observed that neither alkaline nor acidic conditions are congenial for the growth and sporulation of the bio-agent. Jayaswal et al., (2003) recorded optimum growth and sporulation of Trichoderma viride between $\mathrm{pH} 4.5$ to 5.5. The growth and sporulation decreased with either decreasing the $\mathrm{pH}$ below 4.5 or above 5.5 respectively, above $\mathrm{pH} 6.0$ with increasing the $\mathrm{pH}$, the growth and sporulation decreased proportionately. At $\mathrm{pH} 8$ and 8.5 the growth and sporulation were very poor. At $\mathrm{pH} 9$, no growth of $T$. viride could be observed. Farooq et al., (2005) were studied In vitro effect of $\mathrm{pH}$ levels on mycelial growth of $F$. oxysporum f. sp. ciceri. He found the most suitable $\mathrm{pH}$ level for growth of fungus was 7.0 and 6.0.

\section{References}

Choi, Young; Gi-Tae, J., Joung-Sik, C. and Yeong-Geun, C. (2003). Physiological characteristics of green mold 
(Trichoderma sp.) isolated from oyster mushroom, Mycobiology, 31(3): 139-144.

Cooke (1954). Antibiot. Chemother. 4:657.

Dandge V. S. (2012). Effect of some fungicide on growth (in $\mathrm{mm}$ ) of Curvularia lunata, Fusarium equiseti, Phoma vulgaris and Botryodiplodia theobromae. Journal of Experimental Sciences 3(3): 19-20.

Devi, Prameela; Prabhakaran, N., Kamil, Deeba; Pandey, Pankaj and Jyoti, L. B. (2012). Characterization of Indian native isolates of Trichoderma sp. and assessment of their bio-control efficiency against plant pathogens, African Journal of Biotechnology, 11(85): 15150-15160.

Elad, Y., Chet, I., and Henis, Y. (1981). A selective medium for improving qualitative isolation of Trichoderma sp. from soil, Phytoparasitica, 9: 59-67.

Farooq, Sajid; Muhammad Iqbal and Rauf, Abdul (2005). Physiological Studies of Fusarium oxysporum f. sp. ciceri, International Journal of Agriculture \& Biology, 7(2): 275-277.

Guinea, J., Peláez, T., Alcalá, L. and Bouza, E. (2005). Evaluation of Czapeck agar and Sabouraud dextrose agar for the culture of airborne Aspergillus conidia. Diagnostic Microbiology and Infectious Disease 53 (4): 333-334.

Harman, G. E., Latorre, B., Agosin, S., San Martin, R., Riegel, D. G., Nielsen, P. A., Tronsmo, A. and Pearson, R. C. (1996). Biological and integrated control of Botrytis bunch rot of grape using Trichoderma sp. Biological control, 7: 259-266.

Jayaswal, R. K., Singh, R. and $\mathrm{Yu} \mathrm{Su}$ Lee (2003). Influence of physiological and environmental factors on growth and sporulation of or antagonistic strains of Trichoderma virideRSR-7, Microbiology, 31(1): 36-41.
Kubicek, C. P. and Penttiläme (1998). Regulation of production of plant polysaccharide degrading enzymes by Trichoderma. Trichoderma and Gliocladium. Enzymes, Biological Control and Commercial Applications. 49-71.

Lawrence C. Parks (1997). Handbook of Microbiological Media, second edition, Atlas, R.M.

Mustafa, A., Khan, M. A., Inam-ul-Haq, M., Pervez, M. A. and Ummad-ud-Din, U. (2009). Usefulness of different culture media for in vitro evaluation of Trichoderma, Phytopathol., 21(1): 83-88.

Nashwa M. A., Sallam, KAM abo-Elyouusr, M. A. and Hasan, E. (2008). Evaluation of Trichoderma sp. as bio-control agents for damping off and wilt dieses of Phaseolus vulgaris L. and efficacy of suggested formula. Egypt. J. Phytopathol., 36(1-2): 81-93.

Sheila A., Okoth and Odhiambo, J. (2009). Influence of soil chemical and physical properties on Trichoderma spp. Occurrence in Taita region, Tropical and Sub tropical Ecosystems, 11: 403-413.

Smith, N. R. and V. T. Dawson. (1944). The bacteriostatic action of Rose Bengal in media used for the plate counts of soil fungi. Soil Sci. 58:467-471.

Sundara Rao, W. V. B. and Sinha, M. K. (1963). Ind. J., Agric. Sci., 33:272.

Thom and Church (1926). The Aspergilli: 39. Vanderzant, C. and Splittstoesse, D. F. (1992). Compendium of methods for the microbiological examination of food, $3^{\text {rd }}$ Ed. American Public Health Association, Washington, D.C.

Williams, Peter W. and Phillips, Glyn O. (2000). "Chapter 2: Agar". Handbook of hydrocolloids. Cambridge: Woodhead, 28pp.

\section{How to cite this article:}

Mishra, R.P., Manjul Pandey and Mukesh Srivastava. 2018. Morphological and Physiological Analysis of Bio-Control Agent (Trichoderma viride). Int.J.Curr.Microbiol.App.Sci. 7(05): 14141420. doi: https://doi.org/10.20546/ijcmas.2018.705.168 